\title{
A case of lead poisoning due to snooker chalk
}

\author{
P I Dargan, P H Evans, I M House, A L Jones
}

\begin{abstract}
A 3 year, 9 month old child with pica presented with a blood lead concentration of $1.74 \mu \mathrm{mol} / 1$ (360 $\mu \mathrm{g} / \mathrm{l})$. The source of poisoning was snooker chalk (lead content $7200 \mu \mathrm{g} / \mathrm{g}$ ). She was treated with intravenous calcium disodium edetate chelation. Thirty months later her blood lead was $0.39 \mu \mathrm{mol} / 1(80 \mu \mathrm{g} / \mathrm{l})$. This case illustrates the need to be vigilant for more unusual causes of lead poisoning in the home.
\end{abstract}

(Arch Dis Child 2000;83:519-520)

Keywords: lead poisoning; chelation treatment

Mean blood lead concentrations in the United Kingdom have fallen over the last 10 years, by a factor of 3.6 to 5.0 in children. ${ }^{1}$ This is due to the reduced use of leaded paint and lead solder in food tins, improved industrial hygiene, and increased unleaded petrol use. However, cases of clinically significant lead poisoning continue to occur. ${ }^{2}$ This case report illustrates the difficulties that can arise in trying to identify the source of lead poisoning in a child.

\section{Case report}

A 3 year, 9 month old girl was taken to her general practitioner with a suspected viral upper respiratory tract infection. Further questioning revealed that she had a poor diet; she would only drink milk and was not interested in solid foods. She had a 9 to 12 month history of pica of soil and concrete. There was no history of constipation or bony/abdominal pain. Her previous medical history included mild eczema and wheezing with upper respiratory tract infections. She was the product of a normal delivery and had normal developmental milestones. She was not on regular medication. Her parents were from India, but she had been born and brought up in the UK.

On examination, her weight and height were on the 3rd centile, and she had conjunctival pallor. Neurological examination was unremarkable.

Initial blood results revealed a haemoglobin level of $6.3 \mathrm{~g} / \mathrm{dl}$, mean corpuscular volume $57.2 \mathrm{fl}$, mean corpuscular haemoglobin $17.4 \mathrm{pg}$, and blood lead concentration $1.74 \mu \mathrm{mol} / 1(360 \mu \mathrm{g} / \mathrm{l}$, table 1$)$. She was started on iron supplements in view of the microcytic, hypochromic anaemia (ferrous fumarate $5 \mathrm{ml}$ twice daily, equivalent to $90 \mathrm{mg}$ elemental iron daily).

An environmental assessment was carried around the home out to identify the source of lead poisoning. Samples taken included paint, plaster, and dust (lead concentrations $98 \mu \mathrm{g} / \mathrm{g}$, $0 \mu \mathrm{g} / \mathrm{g}$, and 0 to $49 \mu \mathrm{g} / \mathrm{g}$ respectively); soil sam- ples (lead concentration $12 \mu \mathrm{g} / \mathrm{g}$ ); and a first run morning water sample (lead concentration $16 \mu \mathrm{g} / \mathrm{l})$. The parents were questioned to try to identify any other lead source, particularly via the use of alternative medicines or surma cosmetics, but there was no such history.

Over the next 18 months, her dietary intake remained poor and she was reluctant to take the iron supplements. Her blood lead initially fell (table 1) to $1.16 \mu \mathrm{mol} / 1(240 \mu \mathrm{g} / \mathrm{l})$ in March 1997. However, it rose again to $2.22 \mu \mathrm{mol} / 1$ $(460 \mu \mathrm{g} / \mathrm{l})$ in July 1997 , and she remained anaemic (haemoglobin $10.4 \mathrm{~g} / \mathrm{dl}$ ). A course of chelation treatment was prescribed, in line with our unit's lead poisoning protocol and American Academy of Pediatrics guidelines. ${ }^{3}$ Because of her previous poor compliance with oral medication, she was not given oral DMSA (meso-2, 3-dimercaptopropanesulphonate), but was admitted for a 5 day course of intravenous calcium disodium edetate $1000 \mathrm{mg} / \mathrm{m}^{2}$ daily, in two divided doses. She tolerated this well and her blood lead fell to $0.68 \mu \mathrm{mol} / 1(140 \mu \mathrm{g} / \mathrm{l}) 14$ days after chelation. Further detailed questioning of her parents whilst she was an inpatient revealed that she was often seen with snooker chalk in her mouth. This chalk (fig 1) was obtained for analysis and showed a lead content of $7200 \mu \mathrm{g} / \mathrm{g}$.

Three months after chelation treatment, her haemoglobin level had risen to $12.2 \mathrm{~g} / \mathrm{dl}$ and her blood lead was $1.16 \mu \mathrm{mol} / 1(240 \mu \mathrm{g} / \mathrm{l})$, in

Table 1 Blood lead ( $\mu$ mol/l) and haemoglobin ( $g / d l)$

\begin{tabular}{llll}
\hline Date & $\begin{array}{l}\text { Blood lead } \\
(\mu m o l l l)\end{array}$ & $(\mu g / l)$ & $\begin{array}{l}\text { Haemoglobin } \\
(\mathrm{g} / \mathrm{dl})\end{array}$ \\
\hline May 1996 & 1.74 & 360 & 6.3 \\
September 1996 & 1.45 & 300 & 8.2 \\
March 1997 & 1.16 & 240 & 9.6 \\
June 1997 & 2.22 & 460 & 10.4 \\
July 1997 & 0.68 & 140 & 11.4 \\
September 1997 & 1.16 & 240 & 12.1 \\
January 1999 & 0.63 & 130 & 12.5 \\
March 2000 & 0.39 & 80 & 13.3 \\
\hline
\end{tabular}

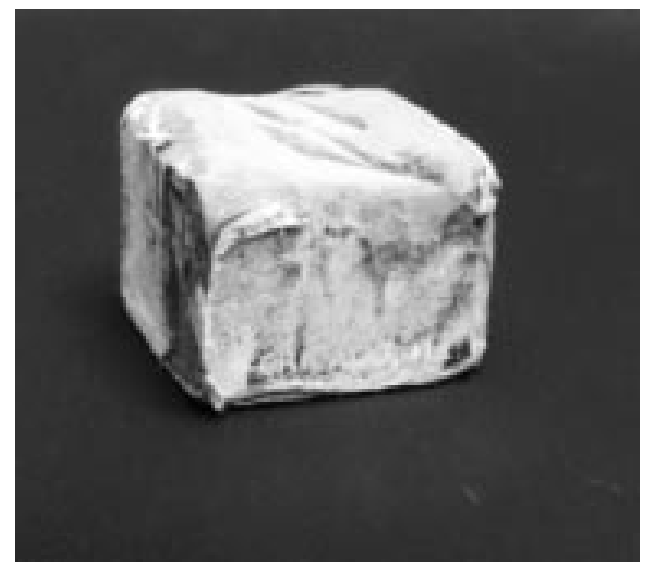

Figure 1 Picture of the snooker chalk 
keeping with redistribution of lead to blood from bone stores. She was lost to follow up until January 1999, when her haemoglobin was $12.5 \mathrm{~g} / \mathrm{dl}$ and blood lead $0.63 \mu \mathrm{mol} / 1(130 \mu \mathrm{g} /$ 1). Her height was on the 40th centile and weight on the 25th centile, and she was progressing normally in school.

Blood lead analysis was carried out using graphite furnace spectrophotometry, and environmental samples were analysed using flame spectrophotometry (IMH).

\section{Discussion}

Exposure to lead in children may occur from environmental sources in the home, recreational sources, or occupational sources via parents. Common sources include leaded paint, lead contaminated dust and soil, airborne lead from leaded petrol and industrial emissions, water contaminated by lead pipes, and food contaminated by lead soldered cans or leaded ceramics. ${ }^{4}$ Lead poisoning has also been reported from the use of surma cosmetics, ${ }^{5}$ following ingestion of a lead foreign body, ${ }^{6}$ due to lead gunshot pellets, ${ }^{7}$ and following the use of traditional remedies such as ayurvedic medicines. $^{8}$

A thorough environmental history, including questioning to exclude unusual sources, is crucial in assessing children with lead poisoning. Ideally, samples should be obtained from the home for analysis to help identify sources and prevent further exposure. This case illustrates that unusual lead sources should always be considered, particularly when common sources have been excluded. Identification of the source of lead poisoning is important because removal of the source is much more effective than chelation treatment in the long term.

This is the first case of lead poisoning due to snooker chalk in Europe. There has been one previous report, from the United States, of snooker chalk as a source of lead: two children were found to have raised blood lead concentrations of $1.69 \mu \mathrm{mol} / \mathrm{l} \quad(350 \mu \mathrm{g} / \mathrm{l})$ and $1.26 \mu \mathrm{mol} / 1(260 \mu \mathrm{g} / \mathrm{l})$ during a routine screening programme (with snooker chalk lead contents of 4030 and $7000 \mu \mathrm{g} / \mathrm{g}$ respectively). ${ }^{9}$

When snooker chalk is used, a fine dust is formed that will contaminate the snooker table, floor, clothes of the user, and surrounding soft furnishings. Pica of contaminated snooker chalk will provide a considerable risk, as the World Health Organization tolerable daily intake of lead is $3.5 \mu \mathrm{g} / \mathrm{kg} .{ }^{10}$ A $15 \mathrm{~kg}$, 4 year old child would only need to ingest $7.4 \mathrm{mg}$ of snooker chalk (with a lead content of $7000 \mu \mathrm{g} /$ g) per day to be at risk of lead accumulation. Snooker chalks therefore pose a significant risk to young children and "lead free" snooker chalks should be used preferentially, particularly if children are in the home.

1 Delves HT, Diaper SJ, Oppert S, et al. Blood lead oncentrations in the United Kingdom have fallen substantially since 1984. BMF 1996;313:883-4.

2 Dargan PI, Jones AL, House IM, Murray VSG. The treatment of lead poisoning-clinical experience of the National Poisons Information Service (London) 19971998 [abstract]. F Toxicol Clin Toxicol 1999;37:626-7.

3 Committee on Drugs, American Academy of Pediatrics. Treatment guidelines for lead exposure in children. Pediatrics 1994;96:155-60.

4 Landrigan PJ. Occupational and paediatric aspects of lead toxicity. Vet Hum Toxicol 1983;25:1-6.

5 Ali AR, Smales OR, Aslam M. Surma and lead poisoning. BMF 1978;2:915-16.

6 Hugelmeyer CD, Moorhead JC, Horenblas L, Bayer MJ. Hugelmeyer CD, Moorhead JC, Horenblas L, Bayer MJ.
Fatal lead encephalopathy following foreign body Fatal lead encephalopathy following foreign
ingestion: case report. $\mathcal{F}$ Emerg Med 1988;6:397-400.

7 Meggs WJ, Gerr F, Aly MH, et al. The treatment of lead poisoning from gunshot wounds with succimer. $\mathcal{F}$ Toxicol Clin Toxicol 1994;32:377-85.

8 Bayly GR, Braithwaite RA, Sheehan TM, Dyer NH, Grimley C, Ferner RE. Lead poisoning from Asian traditional remedies in the West Midlands-report of a series of five cases. Hum Exp Toxicol 1995;14:24-8.

9 Miller MB, Curry SC, Kunkel DB et al. Pool cue chalk: a source of environmental lead. Pediatrics 1996;97:916-17.

$10 \mathrm{FAO} / \mathrm{WHO}$. WHO expert committee on food additives vol 21: toxicological evaluation of certain food additives and contaminants. Cambridge: Cambridge University Press, 1987:223-55. 